\title{
PATTERnS OF MORBIDITY AND MORTALITY AMONGST MOTORCYCLE RIDERS AND THEIR PASSENGERS IN Benin-City Nigeria: ONe-Year ReVIEW
}

\author{
M. A. Nzegwu ${ }^{1}$, J. U. Aligbe ${ }^{1}$, A. A. F. Banjo ${ }^{2}$, W. Akhiwu ${ }^{1}$ and C. O. Nzegwu ${ }^{3}$ \\ ${ }^{1}$ Department of Morbid Anatomy, University of Benin Teaching Hospital, Benin City, Nigeria \\ ${ }^{2}$ Department of Pathology, College of Medicine, University of Lagos, Lagos, Nigeria \\ ${ }^{3}$ Grace Eye Clinic, Benin City, Nigeria \\ Reprint requests to: Dr. M. A. Nzegwu, Department of Morbid Anatomy University of Nigeria Teaching Hospital, \\ P. .M. B. 01125, Enugu, Nigeria. E-mail: martin_nze@yahoo.com
}

\begin{abstract}
Objective: To evaluate patterns of morbidity and mortality among bike riders and pillion seat passengers involved in road traffic accidents in Benin-City Nigeria between August 2003-July 2004.

Methods: A total of Fifty-one bike riders and pillion seat passengers, who participated in this study were part of a larger study, involved in a road traffic accident and were brought to the accident and emergency unit of either the University of Benin Teaching Hospital (UBTH) or the State Specialist Hospital between August 2002-July2003.The injured ones were examined and dead patients had an autopsy done on them

Results: A total of 51 cases of bikes riders/pillion seat passenger accidents were recorded representing $18 \%$ of total accidents. 35 motorbike riders/pillion seat passengers were struck down by cars (68.6\%). Seven bike riders/pillion seat passengers (13.5\%) were struck by articulated vehicles. 7 bike riders/pillion seat passengers representing $13.5 \%$ of cases were stuck by buses, 2 (3.9\%) pillion seat passengers fell of bikes from epilepsies and sustained secondary injuries. Males were more in number with a ratio of $2.5 ; 1$. One hundred percent $(100 \%)$ or all motorcyclist and their passengers did not use helmets.

Conclusion: Cars struck down most bike riders and their pillion seat passengers. Males were more than females in number. The commonest autopsy findings as cause of death was intra-cranial hemorrhage preventable by the use of crash helmets.
\end{abstract}

Key words: Road traffic accident, motorcycle riders, morbidity, mortality

\section{Résumé}

Objectif: pour évaluer la morbidité et la mortalité parmi les motocyclistes et leur passagers qui sont victimes des accidents de circulation dans la cite de Bénin au Nigeria entre Août 2003 et Juillet 2004

Méthodes: une cinquante des motocyclistes et leurs passagers participants dans cette étude, étaient victimes d'un accidents de circulation et ont été amené a la salle d'urgence et d'accidents du centre hospitalier universitaire du Bénin ou de l'hôpital spécialiste de l'état entre Août 2002 et juillet 2003. On a examine les blesses et quant aux gens morts, on leur a fait une autopsie.

Résultat: on a noté une cinquantaine des motocyclistes et leur passagers qui étaient victimes d'accidents routiers. Ce bilan représente $18 \%$ de tous les accidents. Trente-cinq motocyclistes étaient renverses par les voitures (68\%), sept motocyclistes et passagers $13.5 \%$ étaient renverses par les autobus, deux passagers sont tombés du moto pendant une attaque d'épilepsie et étaient grièvement blessés Pratiquement tous les motocyclistes se sont méprisés de casque protecteur. 
Conclusions: la plupart des motocyclistes et passagers étaient renversés par les voitures. Parmi les victimes, les hommes étaient plus nombreux que les femmes. Partout dans les résultats de l'autopsie, la cause la plus courante des morts était l'hémorragie intracrânienne.

Mots clés: accidents de circulation, motocyclistes, morbidité, mortalité

\section{Introduction}

The motorcycle as a commercial means of transport became very popular nationwide as an intra city means of commercial transport from the late 1980s due to economic downturn. In Nigeria today almost all income groups except the very elite are commuted from one spot to the other within cities and semi urban areas by the motorbike. It has gradually grown to become the most popular means of intra city transportation nationwide. The riders of such bikes are however reputed for crimes, recklessness and increased traffic accident rates, which are often fatal because they are mainly school drop outs, who engage in this trade to make ends meet without any formal training. Despite these shortcomings due to poverty, bad roads, severe traffic congestions and poor or nonexistent functional mass transit in our cities and suburban towns' people still patronize them. We are review the patterns of morbidity and mortality among such bike riders and their pillion seat passengers involved in road traffic accidents in Benin city as a base line data using simple percentages to present facts as clearly as possible.

The agent may be a moving vehicle in which case the primary injuries are to the legs followed by secondary impact wounds when the victim hits the vehicle. Further secondary impact wounds occur when the victim strikes the ground. The injuries sustained by motorcyclist are usually more severe than those of cyclists because of the higher momentum or acceleration and consequently higher speed involved., ${ }^{1,2}$ In certain circumstances, the motorcyclists may hit a stationary object or a stationary vehicle in which case severe head injuries are sustained. Wearing a helmet modifies these injuries. ${ }^{1,2}$ A pillion seat passenger is the person carried on a motorcycle as a passenger. In Nigeria and other developing countries, the motorcycle (Achaba, Express, Okada) is a very common mode of public transportation.It contributes to a proportion to road traffic accident related mortalities and morbidities. ${ }^{1,2}$

\section{Materials and Methods}

Between August 2002 and July 2003, all accident cases that presented to University of Benin Teaching Hospital (UBTH) and Specialist Hospital in Benin City as far as possible were followed up especially those presenting in the two referral health centers, the Central Specialist Hospital and the University of Benin Teaching Hospital. Ethics Committee's approval for both hospital were sought for and received for this study to be done in both hospitals, including using facilities for post mortem examinations. Cooperation was also obtained from the department of the Federal Road Safety Corps in Benin-City. They in turn alerted us of all road traffic accidents (RTA) in the City, from where our study began after patients consent was received.

A simple questionnaire was also administered to informants and conscious participants. Injury patterns were studied and autopsies were carried out on dead victims to ascertain the cause of death following due legal procedures. Samples of venous blood were taken from all bike occupants and screened for blood alcohol levels using the Sunshine and Nenad method of blood alcohol assay $(1953)^{3}$ also called Conway's method (1957) ${ }^{4}$ and Hargers method (1961). ${ }^{5}$ Patterns of morbidity and mortality were then studied, including the use of blood alcohol assay to ascertain the contribution of alcohol levels to the injuries seen. Blood alcohol levels exceeding $70 \mathrm{mg} / \mathrm{dl}$ was considered significant.

\section{Results}

A total of 51 cases of bikes riders/pillion seat passenger accidents were recorded. Table 1 shows the age and sex distribution of the of bike occupants involved in RTAs. The 15 - 44-year group represented the most commonly involved age group. Overall, the M:F ratio was 2.5: 1.

There were 20 pillion seat passengers and 31bike riders, all of which were commercial bikes carrying commuting pillion seat passengers with 34 cases of morbidity and 17 cases of mortality. 35 motorbike riders/pillion passengers were struck down by cars (68.6\%). Of this figure, 14 (27.5\%) sustained primary impact injuries with 8 single limb fractures and 5 double limb fractures. Five (9.8\%) sustained secondary impact injuries with multiple bodily injuries while 17, (33.3\%) sustained secondary injuries with 5 having minor head injuries and 12 dying from fractured skull with intra-cranial hemorrhage (Table 2).

Seven motorbike riders/pillion passengers $(13.5 \%)$ were struck by articulated vehicles 
with $5(9.8 \%)$ having primary impact injuries, mainly double fractures, one (1.96\%) sustained secondary impact injury and subsequently dying from skull fracture and intra-cranial hemorrhage, while another one $(1.96 \%)$ sustained secondary injuries. Seven motorbike riders/pillion passengers representing $13.5 \%$ of cases were stuck by buses, all of which had secondary injuries, with 5 dying from fractured skull and intracranial hemorrhage. Two pillion passengers fell off bikes from epilepsies and sustained secondary injuries, mainly multiple soft tissue injuries. Nineteen cases in all (37.3\%) had serious secondary injuries with 17 bike riders dying from them.

A total of 17 bike riders died mainly from intracranial hemorrhage. Nine of them (52.9\%) who died had a blood alcohol level of $70 \mathrm{mg} / \mathrm{dl}$ were alcohol free while, the remaining 8 bike riders (47.1\%) had a mean blood alcohol levels of about $70 \mathrm{mg} / \mathrm{dl}$ range $(50 \mathrm{mg} / \mathrm{dl}-110 \mathrm{mg} / \mathrm{dl})$. All involved motor-cyclists were commercial, were unlicensed and none used a helmet.

Table 1. Age and sex distribution of motor bike occupants involved in road traffic accidents

\begin{tabular}{|c|c|c|c|c|}
\hline Age (years) & No. & $\%$ & Sex & \\
\hline & & & $M$ & $\mathrm{~F}$ \\
\hline $0-14$ & 16 & 31.4 & 10 & 7 \\
\hline $15-44$ & 26 & 51 & 21 & 5 \\
\hline $45-64$ & 4 & 7.8 & 4 & 0 \\
\hline $65+$ & 3 & 5.9 & 1 & 2 \\
\hline Unspecified & 2 & 3.9 & 1 & 1 \\
\hline Total & 51 & 100 & 37 & 15 \\
\hline
\end{tabular}

Table 2. Pattern of injuries among bike riders and pillion seat passenger

\begin{tabular}{|c|c|c|c|c|c|c|c|}
\hline \multirow[t]{2}{*}{$\begin{array}{l}\text { Mechanism of } \\
\text { accident }\end{array}$} & \multicolumn{2}{|c|}{ Primary impact injuries } & \multicolumn{2}{|c|}{$\begin{array}{l}\text { Secondary impact } \\
\text { injuries }\end{array}$} & \multicolumn{2}{|c|}{$\begin{array}{l}\text { Secondary } \\
\text { injuries }\end{array}$} & \multirow[t]{2}{*}{ Total } \\
\hline & 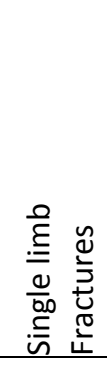 & 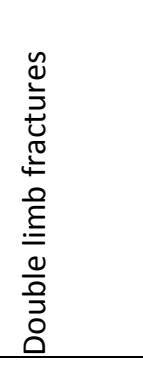 & 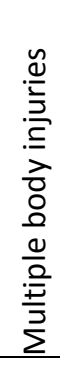 & 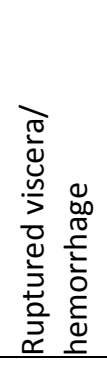 & 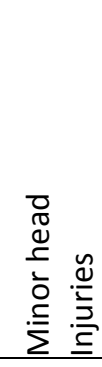 & 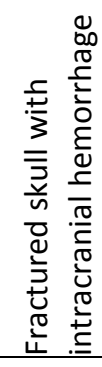 & \\
\hline $\begin{array}{l}\text { Struck by } \\
\text { car }\end{array}$ & 8 & 5 & 5 & - & 5 & 12 & 35 \\
\hline $\begin{array}{l}\text { Struck by } \\
\text { articulated } \\
\text { vehicle }\end{array}$ & 1 & 4 & 1 & - & - & 1 & 7 \\
\hline $\begin{array}{l}\text { Struck by } \\
\text { bus }\end{array}$ & - & - & - & - & 2 & 5 & 7 \\
\hline Epilepsy & - & - & 2 & - & - & - & 2 \\
\hline Total & 9 & 9 & 8 & - & 7 & 18 & 51 \\
\hline
\end{tabular}

\section{Discussion}

The recklessness of bike riders has been highlighted in many studies on their traffic behaviors, ${ }^{6-8}$ however this is the first attempt to study the injury patterns of those involved in road traffic accidents in Benin city, Nigeria. Although The risk of being involved in a road accident is over eight times as great for a motorcycle as for a car, and a motorcyclist is 24 times as likely to be killed or seriously injured per kilometre traveled than a car driver, largely due to the relative inexperience and vulnerability of motor cyclists who tend to be younger than drivers. ${ }^{9}$

More cars and buses were involved in road traffic 
accidents, presumably because they are more in number and the fact that Benin is a gate way to several other states making trunk $A$ roads more common than trunks $B$ and $C$ roads where motorbikes are relatively more for local shuttles. A total of 51 cases of bikes riders/pillion seat passenger accidents representing $18 \%$ of total accidents in the period were recorded accounting for the third largest group of vehicles involved in RTAs.

All motorcyclists did not use crash helmet. The same trend of non-usage of crash helmet was demonstrated in Lagos ${ }^{10}$ and in Kampala. ${ }^{11}$ The study demonstrates that motor bike accidents involving both riders and passengers constituted 51 (18\%) of accident cases which is lower than figures reported from Kampala, Uganda. ${ }^{11}$ The breakdown of results further shows that the younger economically active group of 15-44 years were predominantly involved in motor bike accidents, depleting the work force.

Another observation is that the most common cause of death, which was intracranial hemorrhage from head injury, resulted mostly from knock downs from cars. This may have been prevented or reduced if there was a culture of the use of crash helmets. This finding agrees with the findings of Lawrence et al where the major cause of death in road accident is severe head injury. ${ }^{12}$ Generally fatal head injury did not occur in isolation but in association with skull fractures and sometimes other fractures. In one report, it was found that approximately $50 \%$ of 103 patients with intra-cranial hemorrhage had associated skull fractures. "13 Other causes of motorcycle accidents include collision with articulated vehicles and buses as well as epilepsy.

Generally therefore more bike riders than pillion seat passengers were involved in motorbike accidents morbidity and mortality. Also for most bike riders struck down by cars, the most common type of injury was primary impact injuries with single and double limb fractures. Specifically also noted was the fact that 35 bike riders/pillion seat passengers were struck down by cars (68.6\%). Of this figure, 14 $(27.5 \%)$ sustained primary impact injuries with 8 single fractures and 5 double fractures. 5 (9.8\%) sustained secondary impact injuries with multiple bodily injuries while 17 , (33.3\%) sustained secondary injuries with 5 having minor head injuries and 12 dying from fractured skull with intra-cranial hemorrhage. The mortality frequency was 6 or $11.8 \%$. This is much lower than the figure in a report from Malaysia, which noted that "at any one time, the number of motorcycles is about $45 \%-50 \%$ of total number of vehicles on the road posing the greatest challenge to road safety efforts in Malaysia. ${ }^{14}$ According to one report from Malaysia, motorcyclists constituted about $55 \%-57 \%$ of total number of road accidents and $60 \%$ of traffic fatalities in Malaysia. ${ }^{14}$ Alcohol use may have contributed to the accidents in 8 cases where the average blood alcohol level was $70 \mathrm{mg} / \mathrm{dl}$ (range $55-109 \mathrm{mg} / \mathrm{dl}$ ). Although there is no legally acceptable blood alcohol level in Nigeria, in Britain, $>80 \mathrm{mg}-100 \mathrm{mg}$ alcohol $/ 100 \mathrm{ml}$ of blood while in charge of a car is a statutory offense. ${ }^{15}$ It is also significant that the riders were not licensed.

\section{References}

1. Rafindadi $\mathrm{AH}$. A Handbook of forensic medicine. Amana Publishers Limited, Zaria. 2003; 21-27.

2. Rafindadi AH. A review of Injuries sustained following road traffic accidents and their prevention. Nigerian Journal of Surgical Research. 2000;2:100-104.

3. Varley H. Practical clinical biochemistry. White Friars Press, London. 1969; 123-135.

4. Conway EJ. Micro diffusion analysis and volumetric error. Crosby, Lockwood. 1957;249.

5. Hager RN. In: Stewart CP, Stolman (Eds). Toxicity. Academic Press, New York. 1961; 86. (need chapter title and initials of 2 nd editor)

6. Adekeye EO. The pattern of fractures of the facial skeleton in Kaduna, Nigeria. A survey of 1447 cases. Oral Surg 1980; 49: 490-495.

7. Arotiba GT. Aetiology of facial fractures in Lagos. Niger Postgrad Med J. 1996;3:37-42.

8. Ugboko VI, Odusanya SA, Fagade 00 . Maxillifacial fractures in a semi-urban Nigerian teaching hospital. A review of 442 cases. Int J Oral Maxillofac Surg. 1998;27:286-289.

9. The ROSPA Guide to road safety projects. The Royal society for the prevention of Accidents. June 2005.

10. Falope IA. Motorcycle accidents in Nigeria a new group at risk. West Afr J Med. 1991;10:187-189.

11. Andrews CN, Kobusingye OC, Lett R. Road traffic accident injuries in Kampala. East Afr Med J. 1999;76:189-194.

12. Marshall LF, Gautille T. The outcome of Severe closed head injury. J Neurosurg. 1991;75:S28S36.

13. Abdul Aziz A. Computed Tomography of the brain in predicting outcome of traumatic intracranial hemorrhage in adult patients. Dissertation submitted for the degree of Master of Medicine (Rad), Malaysia, 1998

14. Abdul K. Review of global menace of road accidents with special to refrence to Malaysia: A social perspective. Malaysian J Med Sci. 2003;10:31-39.

15. Laurence DR, Bennett PN. Clinical pharmacology. Churchill Livingstone, Edinburgh. 1999; 272. 